\title{
High glucose and bupivacaine-induced cytotoxicity is mediated by enhanced apoptosis and impaired autophagy via the PERK-ATF4-CHOP and IRE1-TRAF2 signaling pathways
}

\author{
YONGZHE LIU ${ }^{1 *}$, LI SUN $^{1 *}$, YAQUN MA $^{1}$, BIYU WEI $^{2}$, MINGLONG GAO $^{1}$ and LIXIN SHANG ${ }^{3}$ \\ ${ }^{1}$ Department of Anesthesiology, 7th Medical Center, General Hospital of PLA, Beijing 100700; ${ }^{2}$ Department of \\ Anesthesiology, Shanxi Medical University, Taiyuan, Shanxi 030000; ${ }^{3}$ Department of Gynecology and Obstetrics, \\ 7th Medical Center, General Hospital of PLA, Beijing 100700, P.R. China
}

Received January 10, 2019; Accepted June 28, 2019

DOI: $10.3892 / \mathrm{mmr} .2019 .10524$

\begin{abstract}
Bupivacaine has previously been reported to induce neurotoxicity, which is further enhanced by high glucose levels. In the present study, the underlying molecular mechanisms via which bupivacaine induces cytotoxicity under high glucose conditions were investigated in cultured human SH-SY5Y cells. In order to identify the optimal concentrations of glucose and bupivacaine that induced cytotoxicity, SH-SY5Y cells were treated with $30-100 \mathrm{mM}$ glucose and 0.5-1.0 $\mathrm{mM}$ bupivacaine. Based on the dose response experiments, $50 \mathrm{mM}$ glucose and $0.5 \mathrm{mM}$ bupivacaine was used in the present study. The effects that 3-MA (autophagy inhibitor) and rapamycin (RAPA; autophagy inducer) exerted on cell apoptosis, autophagy and the expression of protein kinase R-like endoplasmic reticulum kinase (PERK)-activating transcription factor 4 (ATF4)-C/EBP-homologous protein (CHOP) and inositol-requiring enzyme 1 (IRE1)-tumor necrosis factor receptor associated factor 2 (TRAF2) signaling proteins were measured in high glucose and bupivacaine-treated cells. Cell viability was measured using a Cell Counting Kit-8 assay, cell apoptosis was assessed using flow cytometry, and protein expression was determined using western blot analyses. Compared with the control group, high glucose and bupivacaine significantly increased ATF4, CHOP and caspase-12
\end{abstract}

Correspondence to: Dr Lixin Shang, Department of Gynecology and Obstetrics, 7th Medical Center, General Hospital of PLA, 5 Nanxincang Road, Dongcheng, Beijing 100700, P.R. China

E-mail: lyzgao@gmail.com

Dr Minglong Gao, Department of Anesthesiology, 7th Medical Center, General Hospital of PLA, 5 Nanxincang Road, Dongcheng, Beijing 100700, P.R. China

E-mail: pilotdash@yahoo.com

*Contributed equally

Key words: bupivacaine, high glucose, cytotoxicity, apoptosis, autophagy expression, increased apoptosis, and decreased p-IRE1, TRAF2, LC3-II/LC3-I and Beclin1 expression. Promoting autophagy with RAPA partly reversed the high glucose and bupivacaine-induced changes in p-PERK, CHOP, TRAF2, Beclin1, caspase-12 and apoptosis, while inhibiting autophagy with 3-MA further enhanced the changes in ATF4, CHOP, p-IRE1, TRAF2 and apoptosis. High glucose and bupivacaine induced cytotoxicity in SH-SY5Y cells, at least in part, through enhancing cell apoptosis and inhibiting autophagy via the PERK-ATF4-CHOP and IRE1-TRAF2 signaling pathways.

\section{Introduction}

Studies have demonstrated that high and even clinical concentrations of local anesthetics can induce neurotoxicity $(1,2)$. In 1,416 non-diabetic patients receiving a peripheral nerve block in France between Jan 1, 2000 and Dec 31, 2000, the incidence rate of neurological complications was $0.21 \%$, with symptoms including hyperalgesia, dysesthesia and motor dysfunction (3). Patients with diabetes were more likely to develop postoperative neurological damage due to increased sensitivity to local anesthetic-induced neurotoxicity (4), which is consistent with a report that high blood glucose promotes ischemia/hypoxia, resulting in neurotoxicity (5). Furthermore, nerve injury may occur even at a clinical dose of local anesthetics in patients with diabetes $(6,7)$. In patients with preexisting peripheral sensorimotor neuropathy or diabetic polyneuropathy in the Mayo Clinic (Rochester, MN, USA) between 1988 and 2000, the incidence rate of neurological complications following neuraxial anesthesia or analgesia was $0.4 \%$, approximately twice that of the non-diabetic patients (8).

High glucose levels induce mitochondrial damage and apoptosis in nerve cells through reactive oxygen species (ROS)-mediated activation of caspase-3 $(9,10)$. Local anesthetics in combination with high glucose have also been reported to cause endoplasmic reticulum stress (ERS) due to excessive ROS-induced activation of apoptosis and caspase-12 $(11,12)$. In response to external stimuli, such as hypoxia, unfolded and misfolded proteins accumulate in the endoplasmic reticulum (13). During ERS, the unfolded protein response (UPR) is activated through protein kinase R-like endoplasmic 
reticulum kinase (PERK), inositol-requiring enzyme 1 (IRE1) and activating transcription factor 6 (ATF6) signaling pathways, and autophagy is initiated to maintain endoplasmic reticulum homeostasis $(14,15)$. The UPR is a highly conserved and complex process that can slow protein synthesis and accelerate degradation of unfolded and misfolded proteins in order to protect cells. However, persistent ERS activates apoptotic signaling pathways and outweighs the protective effects of autophagy, leading to apoptotic cell death $(16,17)$.

PERK-eukaryotic initiation factor $2 \alpha(\mathrm{eIF} 2 \alpha)$-activating transcription factor 4 (ATF4)-C/EBP-homologous protein (CHOP), IRE1-X box-binding protein-1 (XBP1)-CHOP and IRE1-tumor necrosis factor (TNF) receptor associated factor 2 (TRAF2)-c-Jun N-terminal kinase (JNK) are the major signaling pathways that contribute to ERS-induced autophagy $(18,19)$. When the UPR is activated, glucose-regulated protein 78 (GRP78)/immunoglobulin heavy chain binding protein (Bip) depolymerizes and phosphorylates the transmembrane protein PERK, which phosphorylates and inactivates eIF2 $\alpha$, inhibiting protein expression (20). Both ATF4 and its downstream target CHOP are transcription factors that regulate UPR target genes (21). ATF4, which is activated by phosphorylated (p)-eIF $2 \alpha$, enhances the synthesis and transport of endoplasmic reticulum proteins to promote cell survival (21). With specific endonuclease activity, IRE1 is depolymerized with GRP78/Bip and activated during the UPR. It then targets 26 nucleotide sequences of XBP1 mRNA to form $\mathrm{XBP} 1 \mathrm{~s}$, regulating target gene transcriptional and endoplasmic reticulum-associated degradation (22). In addition, XBP1s enhance degradation of misfolded proteins in the endoplasmic reticulum, and maintain cell homeostasis by recruiting TRAF2 and activating the apoptosis signal-regulating kinase 1 (ASK1)-JNK signaling pathway $(23,24)$.

In contrast, persistent and severe ERS can induce cell apoptosis though PERK and IRE1 signaling (25-27). ATF4 is a key proapoptotic factor that dephosphorylates eIF $2 \alpha$ via transcriptional activation of growth arrest and DNA damage-inducible protein 34 (28). CHOP downregulates antiapoptotic $\mathrm{Bcl}-2$ expression to promote apoptosis (29). In addition, IRE1 inhibits expression of the antiapoptotic protein Bcl-1 and activates proapoptotic proteins, such as Bcl-2-like protein 11, through the IRE1-TRAF2-ASK1-JNK pathway (30-32). Another study suggested that cell apoptosis is initiated when PERK is activated, and IRE1 and ATF6 signaling are downregulated (33). In the ERS-induced cell apoptotic cascade, caspase-12 is activated by intracellular calcium overload, which in turn activates downstream proapoptotic proteins, including caspases-3 and 9, ultimately leading to apoptosis $(34,35)$. Of note, caspase-12 is a key factor in ERS-mediated cell apoptosis (Fig. 1) (36,37).

Therefore, both autophagy and apoptosis are activated during ERS, and cell survival or death depends on the time and intensity of the stimuli, as well as cell type. The roles of PERK and IRE1 signaling pathways in high glucose and bupivacaine-induced cytotoxicity remain largely unknown. In the present study, it was hypothesized that bupivacaine induces cytotoxicity and apoptosis in SH-SY5Y cells cultured in high glucose conditions by inhibiting autophagy through the PERK-ATF4-CHOP and IRE1-TRAF2 signaling pathways. It was also hypothesized that regulating autophagy influences cell apoptosis and expression of key factors in these signaling pathways.

\section{Materials and methods}

Cells and reagents. The SH-SY5Y neuroblastoma cell line (cat. no. 3111C0001CCC000026) was obtained from the Life Science College in Beijing Normal University (Beijing, China). Prior to the experiments in the present study, the human SH-SY5Y cell line was authenticated using short tandem repeat profiling. Cells were cultured in Dulbecco's Modified Eagle's medium (DMEM)/F12 containing 15\% fetal bovine serum (FBS) (cat. no. F2442, Sigma Aldrich; Merck $\mathrm{KGaA}$ ), $100 \mathrm{U} / \mathrm{ml}$ penicillin, and $100 \mu \mathrm{g} / \mathrm{ml}$ streptomycin in an incubator at $5 \% \mathrm{CO}_{2}$ and $37^{\circ} \mathrm{C}$. The culture media was replaced every 2 days.

The reagents used in the present study included the autophagy inhibitor 3-methyladenine (3-MA; Sigma Aldrich; Merck $\mathrm{KGaA}$ ) and the autophagy inducer rapamycin (RAPA; Sigma Aldrich; Merck KGaA), and the following antibodies: p-PERK (human, unconjugated; cat. no. 12814; Signalway Antibody LLC); PERK (human, unconjugated; cat. no. 12379; Signalway Antibody LLC); ATF4 (human, unconjugated; cat. no. 11815; Cell Signaling Technology, Inc.); CHOP (human, unconjugated; cat. no. 2895; Cell Signaling Technology, Inc.); p-IRE1 (human, unconjugated; cat. no. ab124945; Abcam); IRE1 (human, unconjugated; cat. no. ab37073; Abcam); TRAF2 (human, unconjugated; cat. no. 4712; Cell Signaling Technology, Inc.); LC3 (human, unconjugated; cat. no. ab51520; Abcam); Beclin 1 (human, unconjugated; cat. no. ab55878; Abcam); caspase-12 (human, unconjugated; cat. no. ab62484; Abcam); $\beta$-Actin (human, unconjugated; cat. no. sc4778; Santa Cruz Biotechnology, Inc.) and second antibody (Goat Anti-Rabbit IgG, rabbit, HRP; cat. no. ab2761; Abcam).

Study protocol: Part I. Cells were seeded into 96-well plates at a density of $1 \times 10^{4}$ cells/well. In order to observe high glucose-induced cytotoxicity, cells were divided into 11 groups: A control group (receiving no treatment); 30, 40, 50, 75 and $100 \mathrm{mM}$ glucose groups; and 30,40, 50, 75 and $100 \mathrm{mM}$ mannitol groups. Of note, the glucose concentrations used in the present study were supraphysiological for the following reasons: i) Compared with in vivo conditions, a higher level of glucose was required in order to induce cytotoxicity in SH-SY5Y cells (11); and ii) a concentration of $30 \mathrm{mM}$ glucose for 2 weeks was used to induce cytotoxicity in vitro in the SH-SY5Y cells (38).

In order to observe bupivacaine-induced cytotoxicity, cells were divided into 7 groups: A control group (receiving no treatment); and 0.5, 0.6, 0.7, 0.8, 0.9 and $1.0 \mathrm{mM}$ bupivacaine groups. The control groups were cultured in serum-free $\mathrm{DMEM} / \mathrm{F} 12$, and the bupivacaine treatment groups were cultured in serum-free DMEM/F12 containing different concentrations of bupivacaine, respectively. Cell viability was measured at days 1-3 and apoptosis was measured at day 2 .

Study protocol: Part II. Cells were treated with either 3-MA or RAPA in order to investigate the role of autophagy in response to high glucose-induced cytotoxicity and bupivacaine. The 


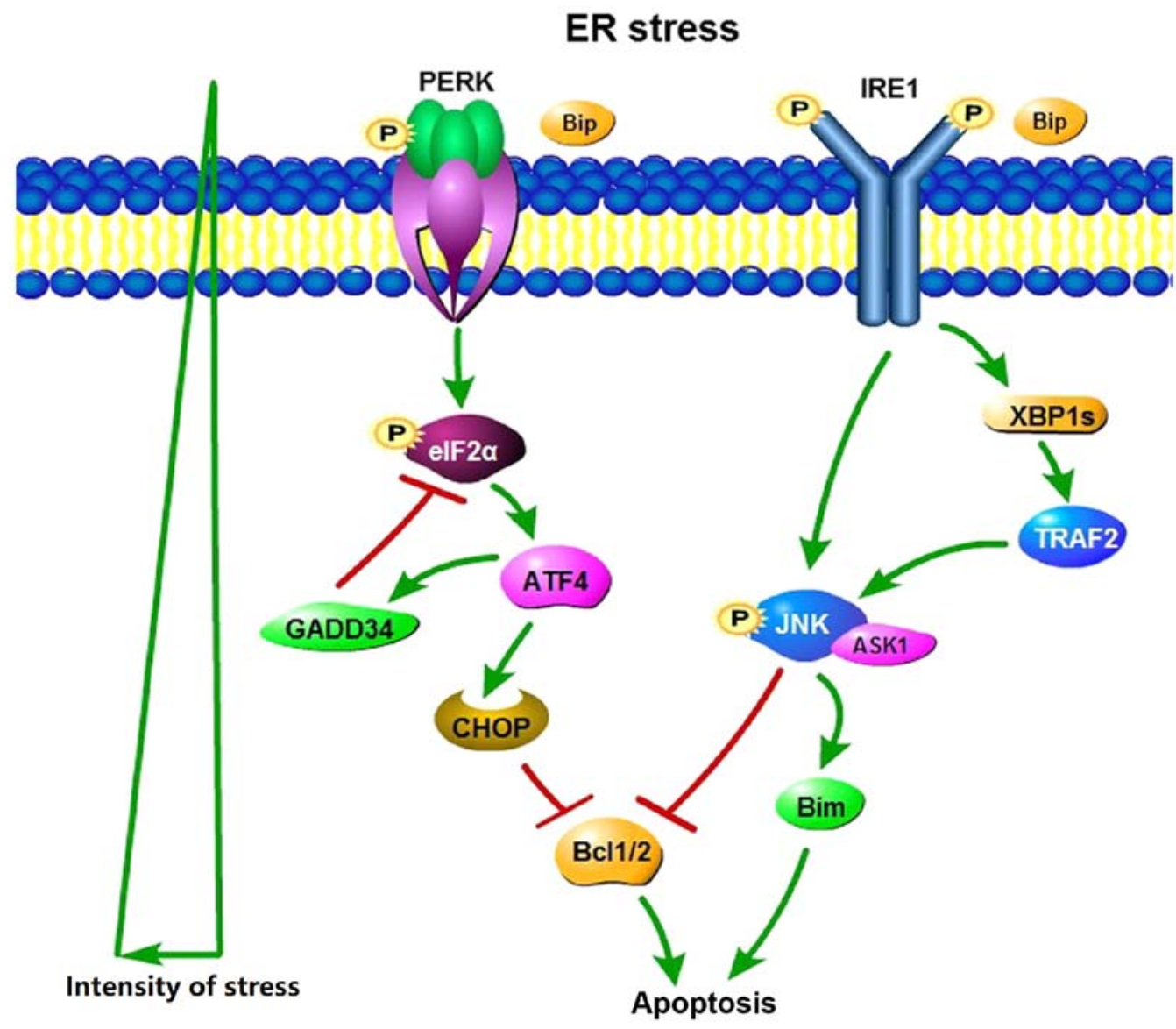

Figure 1. Cell apoptosis under ER stress. PERK-eIF2 $\alpha$-ATF4-CHOP, IRE1-XBP1-TRAF2-JNK are the major signaling pathways that contribute to ERS-induced autophagy. Persistent and severe ERS can induce cell apoptosis though PERK and IRE1 signaling. ATF4 is a key proapoptotic factor. CHOP downregulates anti-apoptotic Bcl-2 expression to promote apoptosis. IRE1 inhibits expression of the antiapoptotic protein Bcl-1 and activates proapoptotic proteins Bim through the IRE1-TRAF2-ASK1-JNK pathway. ASK1, apoptosis signal-regulating kinase 1; ATF4, activating transcription factor 4; Bim, Bcl-2-like protein 11; Bip, immunoglobulin heavy chain binding protein; CHOP, C/EBP-homologous protein; eIF2 $\alpha$, eukaryotic initiation factor $2 \alpha$; ER, endoplasmic reticulum; GADD34, growth arrest and DNA damage-inducible protein 34; IRE1, inositol-requiring enzyme 1; JNK, c-Jun N-terminal kinase; P, phosphate; PERK, protein kinase R-like ER kinase; TRAF2, tumor necrosis factor receptor associated factor 2; XBP1s, X box-binding protein-1s.

cells were divided into 7 groups, as presented in Table I. The protein expression levels of PERK, p-PERK, ATF4, CHOP, IRE1, p-IRE1, TRAF2, LC3-II/LC3-I, Beclin1, and caspase-12 were measured using western blotting.

Cell Counting Kit-8 (CCK-8). Cell viability was determined using a CCK-8 assay (GK3607-500T, Genview) according to the manufacturer's protocol. The optical density values at $450 \mathrm{~nm}$ were measured using a microplate reader (Multiskan MK; Thermo Fisher Scientific, Inc.).

Flow cytometry. Cell apoptosis rates were determined using the Annexin V- FITC/propidium iodide (PI) apoptosis kit (Dingguo Changsheng Biotechnology Co., Ltd.) according to the manufacturer's protocol. Each cell sample of $300 \mu \mathrm{l}$ with $1 \times 10^{6}$ cells was incubated with $5 \mu$ 1 Annexin V-FITC for $15 \mathrm{~min}$ at $37^{\circ} \mathrm{C}$, followed by $5 \mu \mathrm{l}$ PI for $15 \mathrm{~min}$. Cellular fluorescence was measured using a flow cytometer (ACEA NovoCyte; NovoExpress 1.1.0; ACEA Biosciences, Inc.). The apoptosis rate was calculated by adding the early apoptosis (Annexin $\mathrm{V}^{+} / \mathrm{PI}^{-}, \mathrm{Q} 4$ ) and late apoptosis (Annexin $\mathrm{V}^{+} / \mathrm{PI}^{+}$, Q2). The preliminary results revealed no difference following RAPA and 3-MA treatments in normal cells (data not shown), and the apoptosis rates in groups $\mathrm{C}, \mathrm{H}, \mathrm{HB}, \mathrm{HRB}$ and $\mathrm{HMB}$ were evaluated.

Western blot analysis. At the end of cell culture, cells were washed twice with $0.9 \% \mathrm{NaCl}$ at $4^{\circ} \mathrm{C}$. The total protein in each well was extracted using $100 \mu 1$ RIPA lysis buffer containing a protease inhibitor (WB-0071; Dingguo Changsheng Biotechnology Co., Ltd.) for $3 \mathrm{~min}$ on ice. Homogenates were centrifuged at $12,800 \mathrm{x}$ g for $20 \mathrm{~min}$ at $4^{\circ} \mathrm{C}$. Protein concentrations were determined using a bicinchoninic acid protein assay kit (Shanghai Biyuntian Biotechnology Co., Ltd.). The supernatants were used for western blot analysis. Proteins $(50 \mu \mathrm{g})$ were separated via $12 \%$ SDS-PAGE, transferred to nitrocellulose membranes, blocked in $5 \%$ skimmed milk at $37^{\circ} \mathrm{C}$ for $1 \mathrm{~h}$, and incubated overnight at $4^{\circ} \mathrm{C}$ with anti-LC3 $(1: 3,000)$, anti-caspase-12 (1:1,000), anti-PERK $(1: 2,000)$, anti-p-PERK $(1: 2,000)$, anti-ATF4 (1:1,000), anti-CHOP (1:1,000), anti-IRE1 (1:3,000), anti-p-IRE1 (1:3,000), anti-TRAF2 $(1: 1,000)$, anti-Beclin-1 $(1: 1,000)$ and anti- $\beta$-actin $(1: 5,000)$ primary antibodies. The membranes were then incubated for $2 \mathrm{~h}$ at room temperature with appropriate secondary antibody (Goat Anti-Rabbit IgG, 1:5,000). The blots were visualized using an enhanced chemiluminescence detection system (Cell 
Table I. Groupings in the study protocol (part II).

\begin{tabular}{|c|c|c|c|}
\hline Group C & $\begin{array}{c}\text { Culture for } 24 \mathrm{~h} \\
\text { Serum-free DMEM/F12 }\end{array}$ & $\begin{array}{c}\text { Culture for } 2 \mathrm{~h} \\
\text { Serum-free DMEM/F12 }\end{array}$ & $\begin{array}{c}\text { Culture for } 24 \mathrm{~h} \\
\text { Serum-free DMEM/F12 }\end{array}$ \\
\hline Group RAPA & $\begin{array}{l}\text { Serum-free DMEM/F12 + } \\
10 \mathrm{nmol} / \mathrm{l} \mathrm{RAPA}\end{array}$ & $\begin{array}{l}\text { Serum-free DMEM/F12 + } \\
10 \mathrm{nmol} / \mathrm{l} \mathrm{RAPA}\end{array}$ & $\begin{array}{l}\text { Serum-free DMEM/F12 + } \\
10 \mathrm{nmol} / \mathrm{l} \mathrm{RAPA}\end{array}$ \\
\hline Group 3-MA & $\begin{array}{l}\text { Serum-free DMEM/F12 + } \\
1 \mathrm{mmol} / 1 \text { 3-MA }\end{array}$ & $\begin{array}{l}\text { Serum-free DMEM/F12 + } \\
1 \mathrm{mmol} / 1 \text { 3-MA }\end{array}$ & $\begin{array}{l}\text { Serum-free DMEM/F12 + } \\
1 \mathrm{mmol} / 1 \text { 3-MA }\end{array}$ \\
\hline Group H & $\begin{array}{l}\text { Serum-free DMEM/F12 + } \\
50 \mathrm{mM} \text { glucose }\end{array}$ & $\begin{array}{l}\text { Serum-free DMEM/F12 + } \\
50 \mathrm{mM} \text { glucose }\end{array}$ & $\begin{array}{l}\text { Serum-free DMEM/F12 + } \\
50 \mathrm{mM} \text { glucose }\end{array}$ \\
\hline Group HB & $\begin{array}{l}\text { Serum-free DMEM/F12 + } \\
50 \mathrm{mM} \text { glucose }\end{array}$ & $\begin{array}{l}\text { Serum-free DMEM/F12 + } \\
50 \mathrm{mM} \text { glucose }\end{array}$ & $\begin{array}{l}\text { Serum-free DMEM/F12 + } \\
50 \mathrm{mM} \text { glucose }+ \\
0.5 \mathrm{mM} \text { bupivacaine }\end{array}$ \\
\hline Group HRB & $\begin{array}{l}\text { Serum-free DMEM/F12 + } \\
50 \mathrm{mM} \text { glucose }\end{array}$ & $\begin{array}{l}\text { Serum-free DMEM/F12 + } \\
50 \mathrm{mM} \text { glucose }+ \\
10 \mathrm{nmol} / 1 \mathrm{RAPA}\end{array}$ & $\begin{array}{l}\text { Serum-free DMEM/F12 + } \\
50 \mathrm{mM} \text { glucose }+ \\
0.5 \mathrm{mM} \text { bupivacaine }\end{array}$ \\
\hline Group HMB & $\begin{array}{l}\text { Serum-free DMEM/F12 + } \\
50 \mathrm{mM} \text { glucose }\end{array}$ & $\begin{array}{l}\text { Serum-free DMEM/F12 + } \\
50 \mathrm{mM} \text { glucose }+ \\
1 \mathrm{mmol} / 1 \text { 3-MA }\end{array}$ & $\begin{array}{l}\text { Serum-free DMEM/F12 + } \\
50 \mathrm{mM} \text { glucose }+ \\
0.5 \mathrm{mM} \text { bupivacaine }\end{array}$ \\
\hline
\end{tabular}

C, control; RAPA, rapamycin; H, high glucose; HB, high glucose and bupivacaine; HRB, high glucose, RAPA and bupivacaine; HMB, high glucose, 3-MA and bupivacaine. $\mathrm{nM}, \mathrm{nmol} / \mathrm{l} ; \mathrm{mM}, \mathrm{mmol} / \mathrm{l}$.

Signaling Technology, Inc.). Images were processed using Quantity One software (version 4.6; Bio-Rad Laboratories).

Statistical analysis. GraphPad Prism (version 6.0; GraphPad Software Inc.) was used for all the statistical analyses. Data are expressed as the mean \pm standard deviation, and evaluated using one-way analysis of variance followed by Newman-Keuls post hoc tests. $\mathrm{P}<0.05$ was considered to indicate a statistically significant difference.

\section{Results}

High glucose-induces cytotoxicity and cell apoptosis in SH-SY5Y cells. Following culture in serum-free DMEM, the CCK- 8 assay demonstrated decreased cell viability after $30 \mathrm{mM}$ glucose/mannitol treatment at days 2 and 3 (Fig. 2A). Compared with the control group, cell viability significantly decreased in the $40 \mathrm{mM}$ glucose group at day 3 $(\mathrm{P}<0.05$; Fig. 2B), the $50 \mathrm{mM}$ glucose group at day $3(\mathrm{P}<0.01$; Fig. 2C), the $75 \mathrm{mM}$ glucose group at days 2 and $3(\mathrm{P}<0.05$; Fig. 2D), and the $100 \mathrm{mM}$ glucose group at days 1,2 and 3 $(\mathrm{P}<0.05$; Fig. 2E). Compared with the mannitol group, the 50 and $75 \mathrm{mM}$ glucose groups had lower cell viability at day 3 $(\mathrm{P}<0.05$; Fig. 2C and D), and the $100 \mathrm{mM}$ glucose group had lower cell viability at days 1,2 and 3 (Fig. 2E).

At day 2, cell apoptosis was measured using Annexin VFITC/PI staining (Fig. 3A). It was revealed that 50 and $100 \mathrm{mM}$ glucose resulted in significantly higher apoptosis rates $(27.62 \pm 4.09$ and $36.30 \pm 2.59 \%$, respectively) compared with the control $(17.04 \pm 0.39 \%)$ or 50 and $100 \mathrm{mM}$ mannitol groups (18.64 \pm 5.36 and 22.20 $\pm 2.20 \%$, respectively; Fig. 3B).

Collectively, a glucose concentration of $50 \mathrm{mM}$ significantly altered cell viability and apoptosis at day 2 , and was therefore selected as the experimental concentration in the following experiments. Despite a supraphysiological concentration, a $50 \mathrm{mM}$ dose of glucose was required in vitro in SH-SY5Y cells, as described in the Materials and methods section.

Bupivacaine-induced cytotoxicity and cell apoptosis in SH-SY5Y cells. Following culture with serum-free DMEM + 0.5-1.0 mM bupivacaine for 2 days, cell viability was significantly reduced compared with the control group $(\mathrm{P}<0.01$ or 0.05; Fig. 4A). In addition, the bupivacaine groups exhibited significantly higher apoptosis rates compared with the control group ( $\mathrm{P}<0.01$; Fig. $4 \mathrm{~B}$ and $\mathrm{C})$.

Based on these findings, a bupivacaine concentration of $0.5 \mathrm{mM}$, which resulted in a $\sim 17 \%$ reduction in cell viability and 3.5 times of increase in cell apoptosis at day 2 (Fig. 4A-C), was selected for the following experiments.

RAPA and 3-MA modulate the PERK-ATF4-CHOP and IRE1-TRAF2 signaling pathways in SH-SY5Y cells treated with high glucose and bupivacaine. The effects of RAPA and 3-MA treatment on the PERK-ATF4-CHOP and IRE1-TRAF2 signaling pathways under high glucose and bupivacaine treatment conditions were investigated in the present study (Fig. 5A). Neither RAPA nor 3-MA alone significantly affected the expression or phosphorylation of proteins in the PERK-ATF4-CHOP and IRE1-TRAF2 signaling pathways in SH-SY5Y cells under normal conditions. Compared with the control group, p-PERK/PERK was significantly higher in the high glucose $(\mathrm{H})+$ bupivacaine group $(\mathrm{HB} ; \mathrm{P}<0.05$; Fig. 5B-D), ATF4 protein expression was significantly higher in the H, HB, HRB, and HMB groups ( $\mathrm{P}<0.01$; Fig. 5E), CHOP protein expression was significantly higher in the HB group $(\mathrm{P}<0.01$; Fig. 5F), p-IRE1/IRE1 was significantly lower in the 

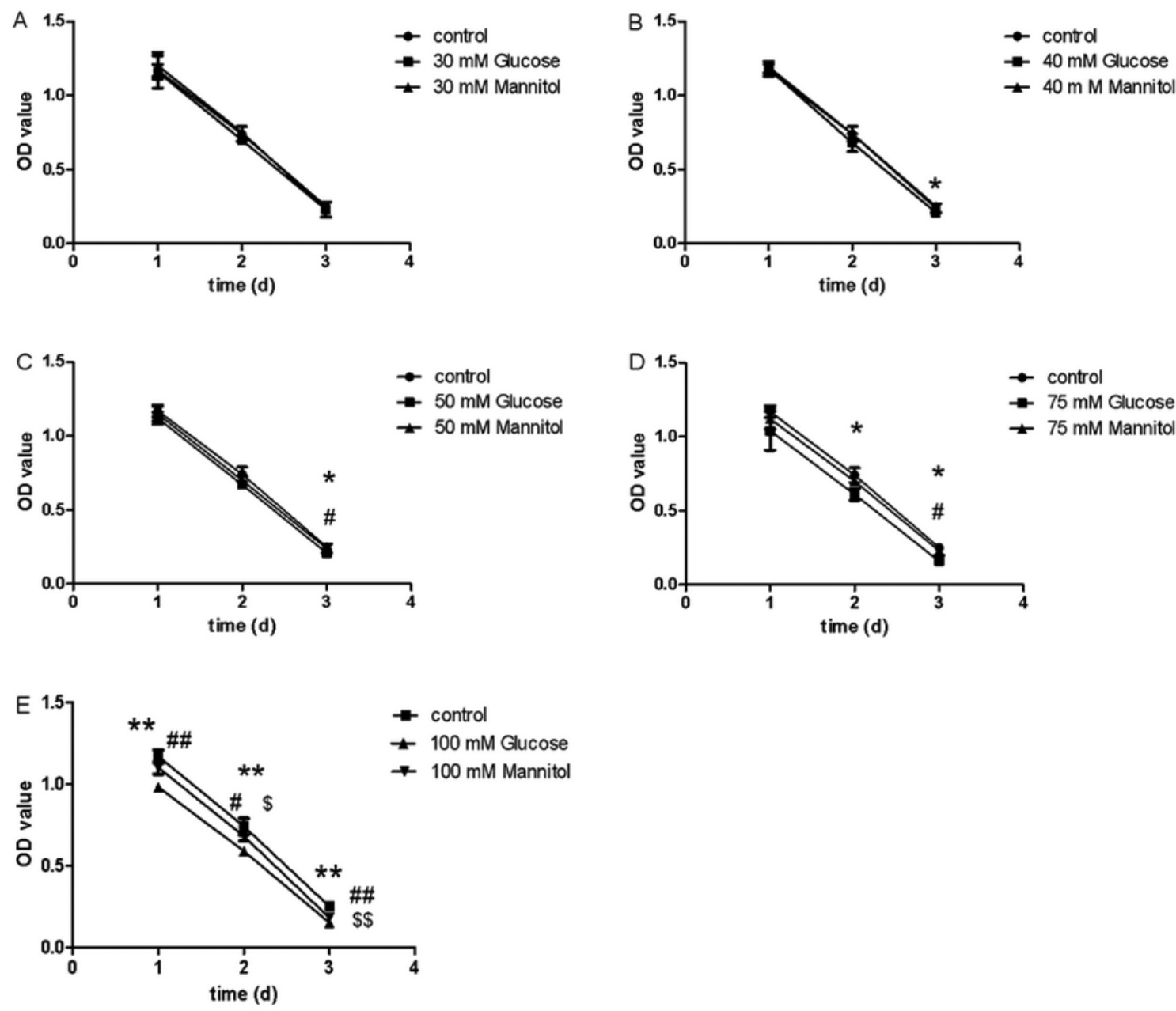

Figure 2. High glucose-induced cytotoxicity in SH-SY5Y cells. Cell Counting Kit-8 assays demonstrating cell viability at days 1-3 following treatment with (A) 30, (B) 40, (C) 50, (D) 75 and (E) $100 \mathrm{mM}$ glucose or mannitol. Data are expressed as the mean \pm standard deviation. $\mathrm{N}=4 /$ group. ${ }^{*} \mathrm{P}<0.05$, ${ }^{* *} \mathrm{P}<0.01$ glucose group vs. control group; ${ }^{\#} \mathrm{P}<0.05$, ${ }^{\#} \mathrm{P}<0.01$ glucose group vs. mannitol group; ${ }^{\mathrm{P}} \mathrm{P}<0.05,{ }^{\$ S} \mathrm{P}<0.01$ mannitol group vs. control group. OD, optical density.

$\mathrm{H}$ and $\mathrm{HB}$ groups $(\mathrm{P}<0.05 ;$ Fig. 5I) and TRAF2 protein expression was significantly lower in the HB group $(\mathrm{P}<0.05 ;$ Fig. 5J).

Compared with the $\mathrm{H}$ group, $\mathrm{CHOP}$ protein expression was significantly higher $(\mathrm{P}<0.01$; Fig. $5 \mathrm{~F})$ and TRAF2 protein expression was significantly lower in the HB group $(\mathrm{P}<0.05$; Fig. 5J).

Compared with the HB group, p-PERK/PERK was significantly lower in the HRB group $(\mathrm{P}<0.01$; Fig. 5D), ATF4 protein expression was significantly higher in the HMB group $(\mathrm{P}<0.01$; Fig. 5E), CHOP protein expression was significantly lower in the HRB group and higher in the $\mathrm{H}+3-\mathrm{MA}+$ bupivacaine (HMB) group $(\mathrm{P}<0.01$; Fig. 5F), p-IRE1/IRE1 was significantly lower in the HMB group $(\mathrm{P}<0.05$; Fig. $5 \mathrm{I})$, and TRAF2 protein expression was significantly higher in the HRB group and lower in the HMB group $(\mathrm{P}<0.05 ;$ Fig. $5 \mathrm{~J})$.

RAPA and 3-MA modulate LC3 and Beclin1 protein expression in SH-SY5Y cells treated with high glucose and bupivacaine. The effects of RAPA and 3-MA treatment on LC3 and Beclin1 protein expression were determined using western blot analysis (Fig. 6A). Neither RAPA nor 3-MA alone affected LC3 and Beclin1 protein expression under normal conditions. Compared with the control group, LC3-II/LC3-I and Beclin1 protein expression were significantly lower in the HB group $(\mathrm{P}<0.01$; Fig. 6B and $\mathrm{C})$. Compared with the $\mathrm{H}$ group, Beclin1 protein expression was significantly lower in the HB group $(\mathrm{P}<0.01$; Fig. $6 \mathrm{C})$. Compared with the HB group, LC3-II/LC3-I and Beclin1 protein expression was significantly higher in the HRB group $(\mathrm{P}<0.01$; Fig. 6B and $\mathrm{C})$.

RAPA and 3-MA modulate cell apoptosis in SH-SY5Y cells treated with high glucose and bupivacaine. Following HRB or HMB treatment, cell apoptosis was measured using Annexin V-FITC/PI staining (Fig. 7A). The cell apoptosis rate was significantly higher in the $\mathrm{H}(33.84 \pm 2.76 \%)$ and HB $(42.55 \pm 2.84 \%)$ groups compared with the control group $(21.48 \pm 1.61 \% ; \mathrm{P}<0.05$ or 0.01$)$, with higher values in the HB group compared with the $\mathrm{H}$ group $(\mathrm{P}<0.01$; Fig. 7B). Compared with the HB group, the apoptosis rate was significantly lower in the HRB group $(36.18 \pm 1.51 \%)$ and higher in the HMB group (49.11 $\pm 3.18 \%$; P<0.01; Fig. 7B).

In addition, caspase-12 expression, a key apoptosis factor, was measured via western blot analyses (Fig. 7C). Neither RAPA nor 3-MA alone affected protein expression of caspase-12 protein expression under normal conditions. Caspase-12 protein expression was significantly higher in 

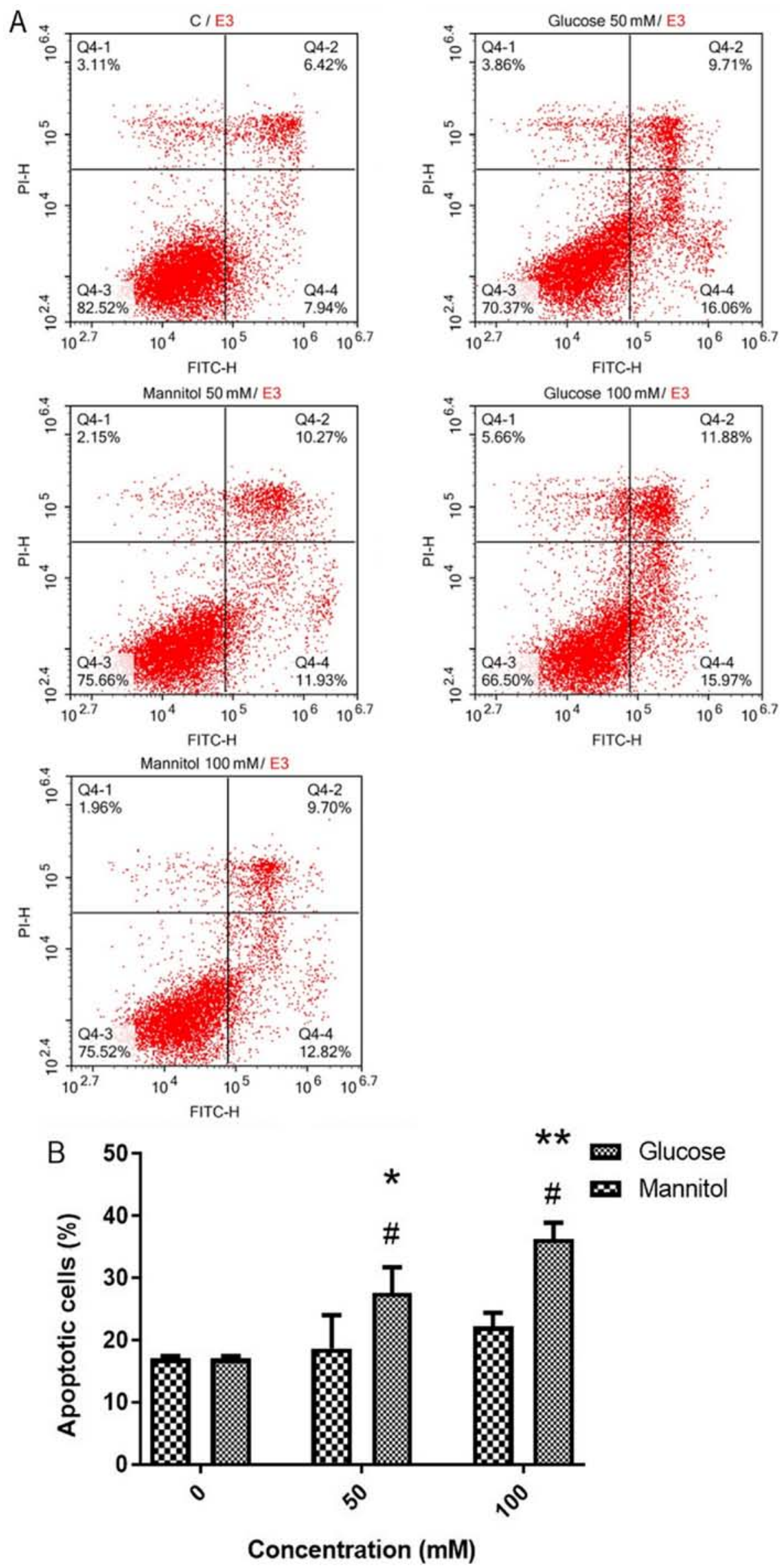

Figure 3. High glucose-induced cell apoptosis in SH-SY5Y cells. (A) Annexin V-FITC/PI staining demonstrating the apoptotic rate at day 2 after treatment with 50 and $100 \mathrm{mM}$ glucose or mannitol. (B) Apoptosis analysis graph. Data are expressed as the mean \pm standard deviation. $\mathrm{N}=4 /$ group. ${ }^{*} \mathrm{P}<0.05$, ${ }^{* *} \mathrm{P}<0.01$ vs. $0 \mathrm{mM} ;{ }^{*} \mathrm{P}<0.05$ vs. mannitol. PI, propidium iodide. 

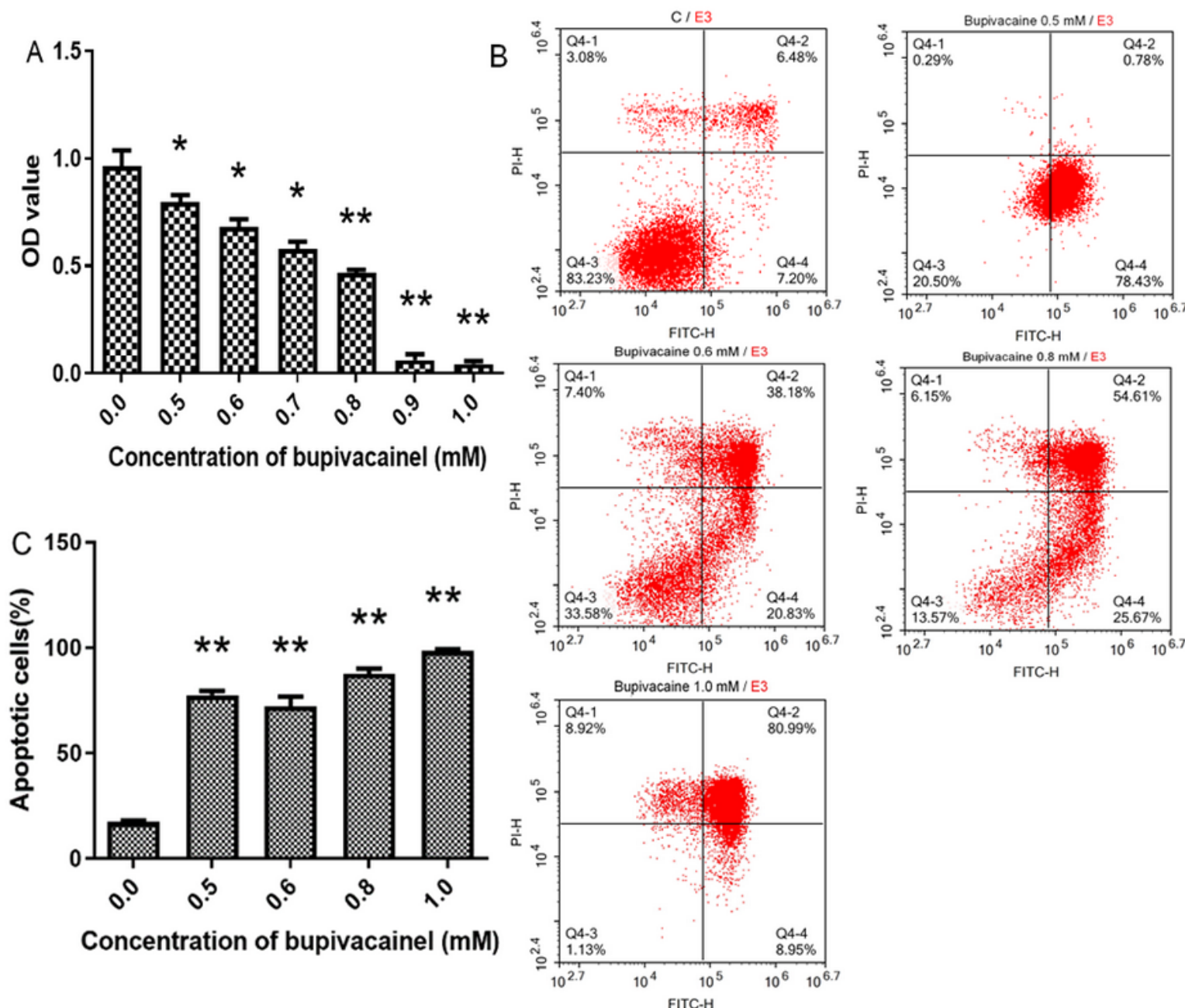

Figure 4. Bupivacaine-induced cytotoxicity and apoptosis in SH-SY5Y cells. (A) Cell Counting Kit-8 assay demonstrating cell viability at day 2 after treatment with $0.5,0.6,0.7,0.8,0.9$ and $1.0 \mathrm{mM}$ bupivacaine. (B) Annexin V-FITC/PI staining demonstrating the apoptotic rate at day 2 after treatment with $0.5,0.6$, 0.8 and $1.0 \mathrm{mM}$ bupivacaine. (C) Apoptosis analysis graph. Data are expressed as the mean \pm standard deviation. $\mathrm{N}=4 / \mathrm{group} .{ }^{*} \mathrm{P}<0.05,{ }^{* *} \mathrm{P}<0.01 \mathrm{vs} .0 \mathrm{mM}$. OD, optical density; PI, propidium iodide.

the $\mathrm{H}$ and $\mathrm{HB}$ groups compared with the control group (all $\mathrm{P}<0.01$ ), with higher levels in the HB group compared with the $\mathrm{H}$ group $(\mathrm{P}<0.05)$. Compared with the HB group, caspase-12 protein expression was significantly lower in the HRB group $(0.75 \pm 0.27 \%)$, but not in the HMB group.

\section{Discussion}

The present study demonstrated that bupivacaine significantly inhibited autophagy in response to high glucose, potentially by activating PERK-ATF4-CHOP signaling and inhibiting IRE1-TRAF2 signaling, which resulted in cell apoptosis due to an imbalance in signaling pathways during the ERS. The autophagy inducer RAPA significantly restored the level of autophagy, decreased cell apoptosis, and reversed high glucose and bupivacaine-induced enhancement of PERK-ATF4-CHOP signaling and impaired IRE1-TRAF2 signaling. The autophagy inhibitor 3-MA led to a greater imbalance between PERK-ATF4-CHOP and IRE1-TRAF2 signaling, resulting in increased apoptosis.

The present study investigated high glucose and bupivacaine-induced cytotoxicity and apoptosis in the SH-SY5Y neuroblastoma cell line, as has been previously reported (11). A previous study demonstrated typical changes in cell morphology under diabetic conditions, and altered expression of a variety of proteins in SH-SY5Y cells subjected to $30 \mathrm{mM}$ glucose for 2 weeks (38). In the present study, cell viability markedly decreased in the 40 and $50 \mathrm{mM}$ glucose groups compared with the control group at day 3, but only the $50 \mathrm{mM}$ glucose group had lower cell viability compared with the mannitol group. Based on these findings, cytotoxicity was primarily induced by high levels of glucose and not by hyperosmosis. As a result, $50 \mathrm{mM}$ glucose was used to induce cytotoxicity in a relatively short period of time. Furthermore, a previous study demonstrated that a higher level of glucose is necessary to induce cytotoxicity in SH-SY5Y cells in vitro when compared with in vivo conditions (11).

During ERS, the UPR is activated to maintain endoplasmic reticulum hemostasis by decreasing the synthesis of new proteins and accelerating the degradation of misfolded or unfolded proteins (39). ERS-induced autophagy was inhibited by knocking down PERK-eIF2 $\alpha$, IRE1 or TRAF2, indicating the essential role that the PERK-eIF2 $\alpha$-ATF4-CHOP and IRE1-TRAF2 signaling pathways play in autophagy (40). 


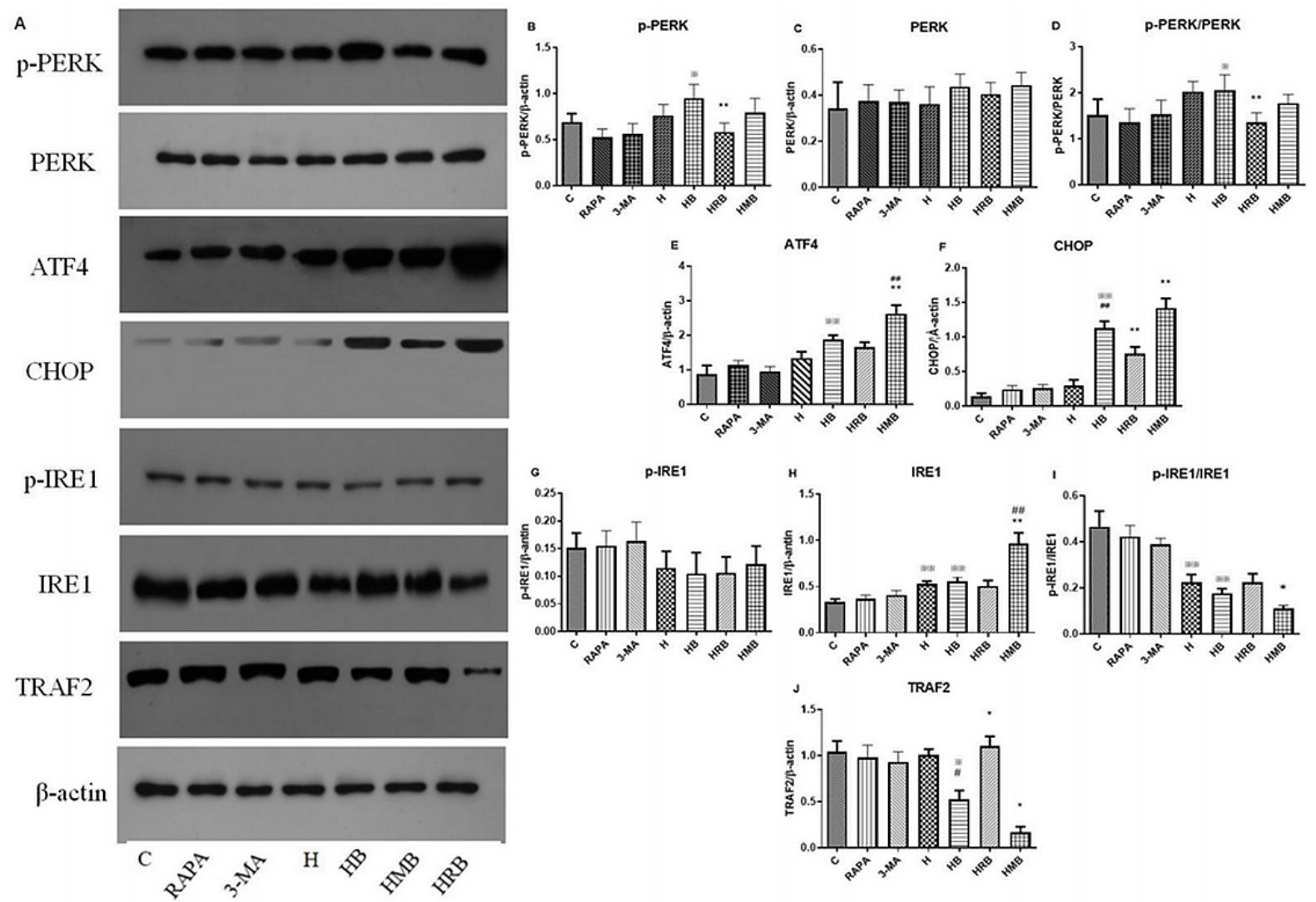

Figure 5. PERK-ATF4-CHOP and IRE1-TRAF2 signaling pathways during autophagy in SH-SY5Y cells. (A) Representative western blotting images. (B-J) Protein expression quantification. Data are expressed as the mean \pm standard deviation. $\mathrm{N}=4$ /group. ${ }^{*} \mathrm{P}<0.05,{ }^{*} \mathrm{P}<0.01$ vs. $\mathrm{C} ;{ }^{\#} \mathrm{P}<0.05,{ }^{\# \prime} \mathrm{P}<0.01$ vs. $\mathrm{H}$; ${ }^{*} \mathrm{P}<0.05,{ }^{* *} \mathrm{P}<0.01$ vs. HB. PERK, protein kinase R-like endoplasmic reticulum kinase; ATF4, activating transcription factor 4; CHOP, C/EBP-homologous protein; IRE1, inositol-requiring enzyme 1; TRAF2, tumor necrosis factor receptor associated factor 2; RAPA, rapamycin; p, phosphorylated; C, control group; $\mathrm{H}$, high glucose group; $\mathrm{HB}$, high glucose + bupivacaine group; HRB, high glucose + RAPA + bupivacaine group; HMB, high glucose + 3-MA + bupivacaine group
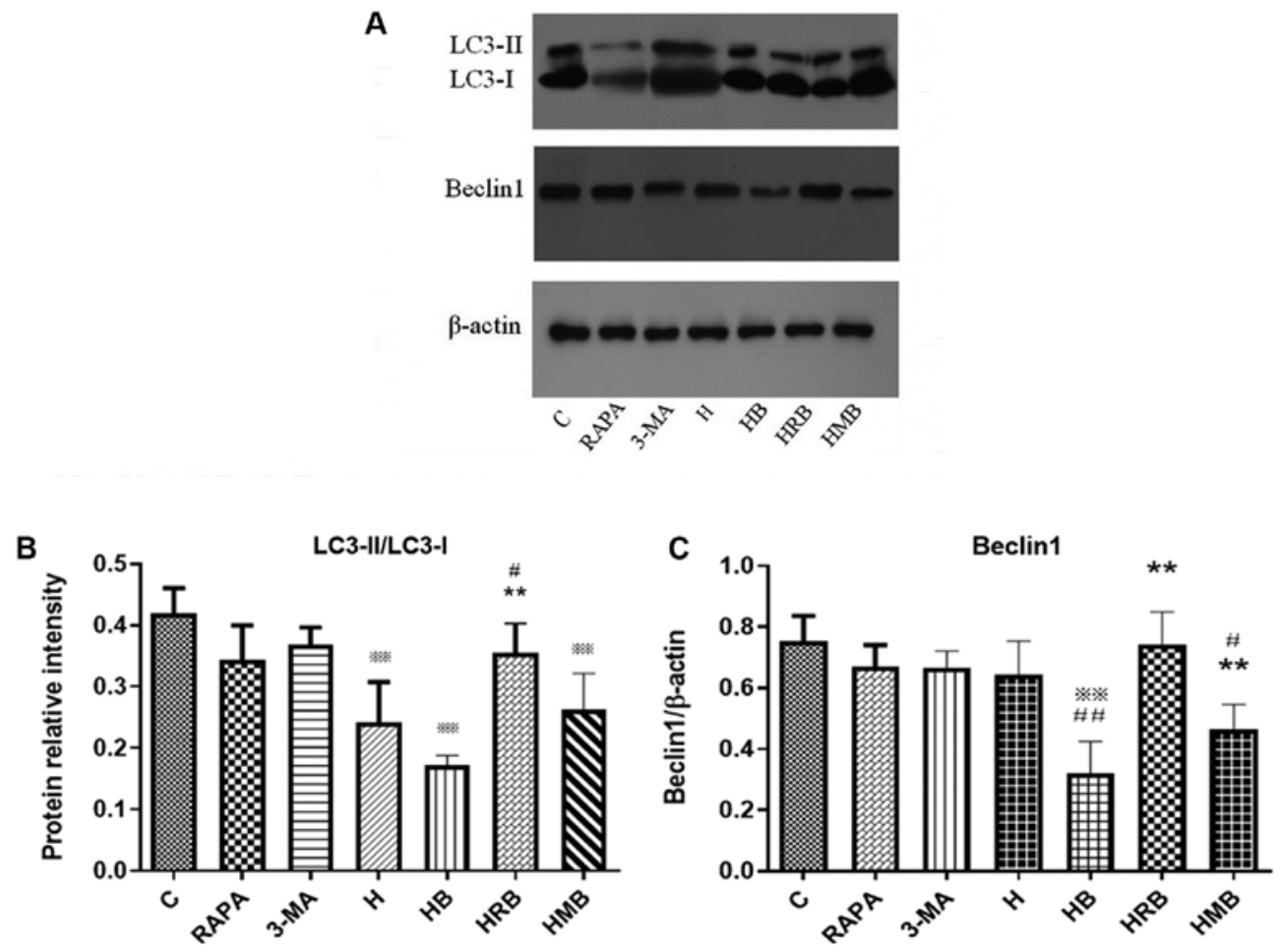

Figure 6. LC3-II/LC3-1 and Beclin1 protein expression during autophagy in SH-SY5Y cells. (A) Representative western blot analysis images. (B and C) Protein expression quantification. Data are expressed as the mean \pm standard deviation. $\mathrm{N}=4$ /group. ${ }^{*} \mathrm{P}<0.01$ vs. $\mathrm{C} ;{ }^{\#} \mathrm{P}<0.05,{ }^{, \#} \mathrm{P}<0.01$ vs. $\mathrm{H}$; ${ }^{* * *} \mathrm{P}<0.01$ vs. HB. C, control group; $\mathrm{H}$, high glucose group; HB, high glucose + bupivacaine group; HRB, high glucose + RAPA + bupivacaine group; HMB, high glucose + 3-MA + bupivacaine group; RAPA, rapamycin. 

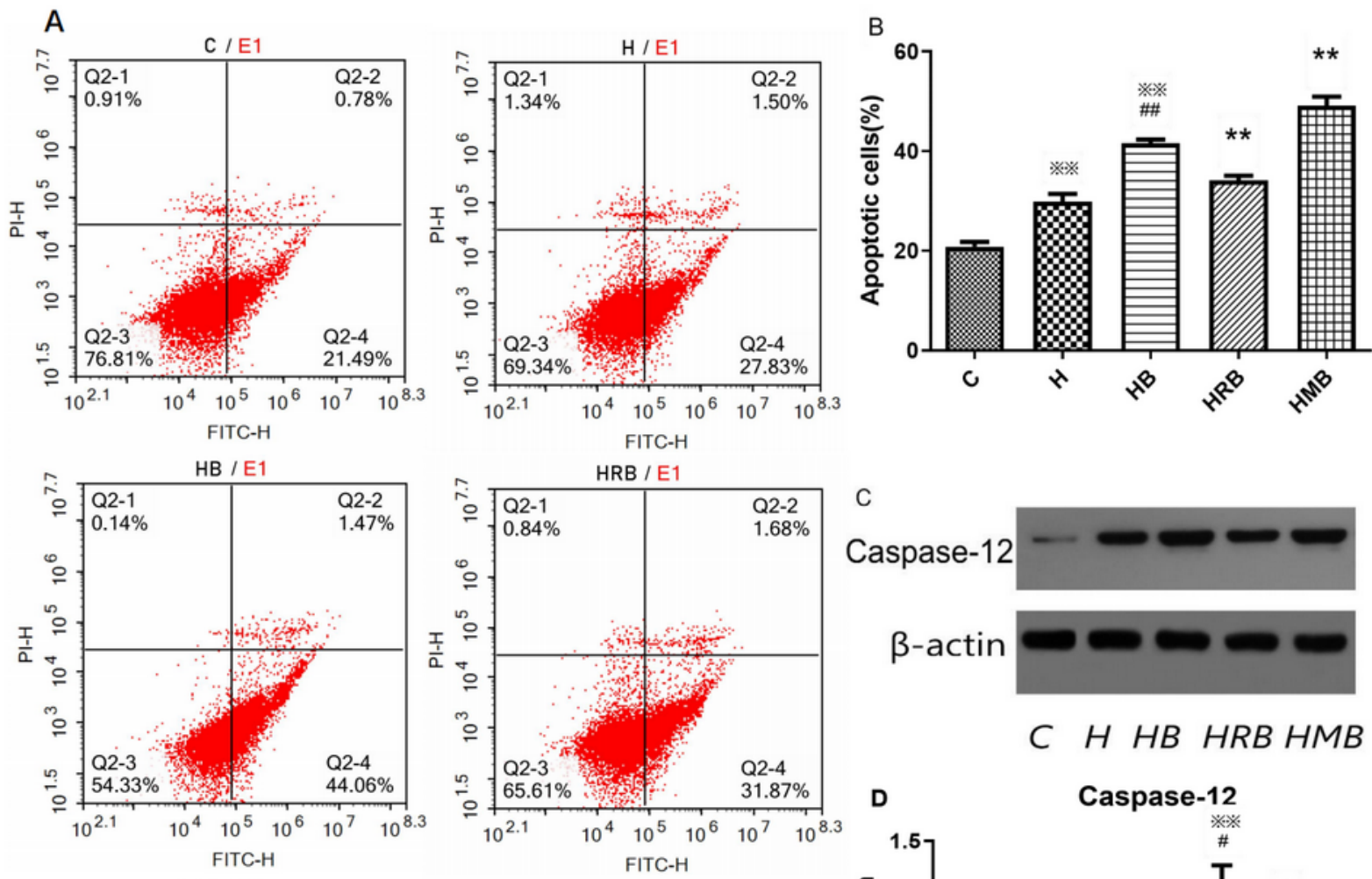

C $H H B$ HRB HMB
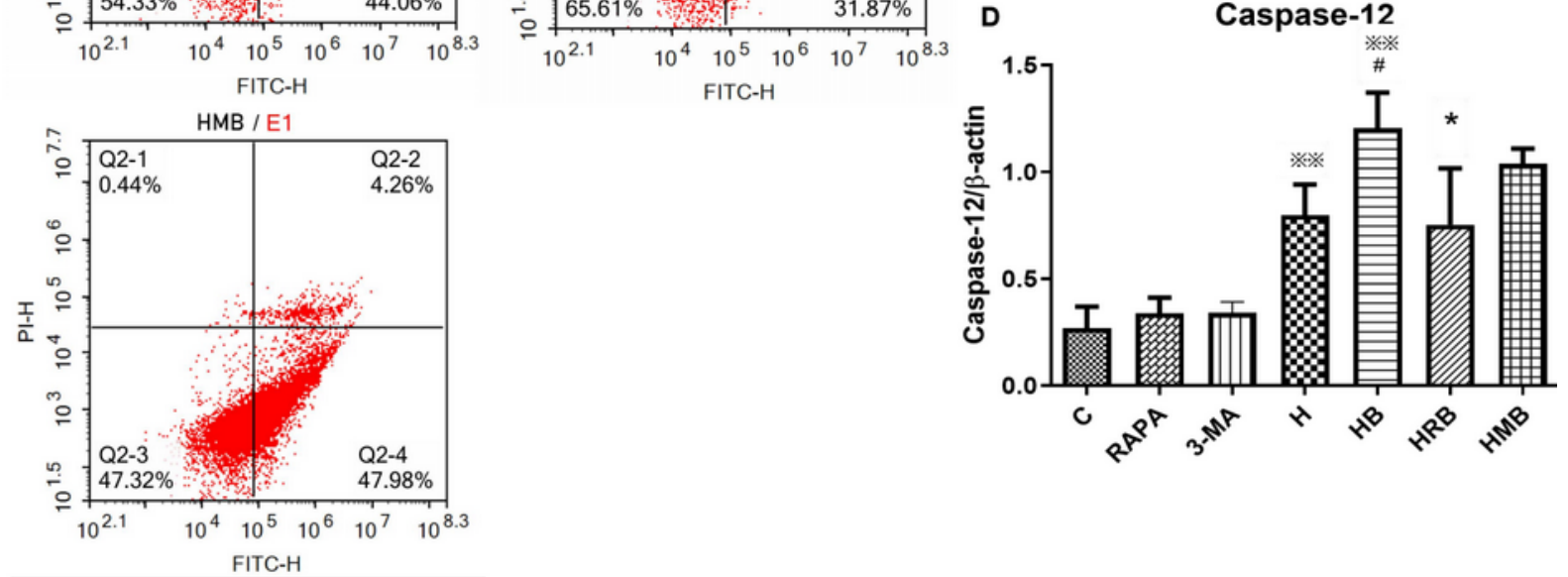

Figure 7. Cell apoptosis and caspase-12 protein expression during autophagy in SH-SY5Y cells. (A and B) Annexin V-FITC/PI staining demonstrating the apoptotic rate at day 2 after treatment with $0.5,0.6,0.8$ and $1.0 \mathrm{mM}$ bupivacaine. (C) Representative western blot analysis images. (D) Protein expression

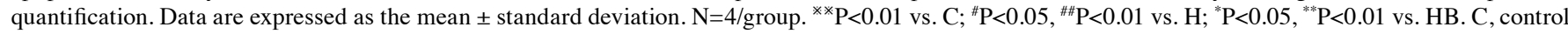
group; H, high glucose group; HB, high glucose + bupivacaine group; HRB, high glucose + RAPA + bupivacaine group; HMB, high glucose + 3-MA + bupivacaine group; PI, propidium iodide; RAPA, rapamycin.

Whether cells become apoptotic depends on the degree of external stimuli and activation of signaling pathways in the UPR (41). Both PERK and IRE1 signaling pathways are activated in acute ERS, but the duration of activation of key factors in these pathways differs (41). Activating the IRE1 signaling pathway and prolonging its duration promotes cell survival, while the activation of the PERK signaling pathway induces apoptotic cell death (41). IRE1 activation has been demonstrated to rapidly decrease within $8 \mathrm{~h}$, with ATF6 activation slightly delayed and PERK activation persisting for $30 \mathrm{~h}$ in acute ERS (41). During the UPR, signaling is disrupted, autophagy is inhibited and cell apoptosis is activated (41). Caspase-12 is initially activated in the ERS-induced cell apoptotic cascade, which activates downstream apoptotic proteins, including caspase-9 and caspase-3, ultimately leading to cell apoptosis $(34,35)$.

In the present study, cells were treated with high glucose for $24 \mathrm{~h}$ followed by bupivacaine for $24 \mathrm{~h}$, which resulted in chronic ERS. In response to high glucose, bupivacaine altered the imbalance of intracellular UPR signals, specifically between activation of PERK-eIF2 $\alpha$-ATF4-CHOP signaling and inhibition of IRE1 signaling. Caspase-12 expression was increased, indicative of cell apoptosis. Consistently, the results of the present study demonstrated that the proapoptotic PERK signaling pathway was activated, and the protective IRE1 signaling pathway was inhibited during high glucose and bupivacaine treatment, which eventually led to apoptosis.

Autophagy is a protective mechanism that maintains endoplasmic reticulum homeostasis and provides energy to the body by digesting proteins, organelles and other dysfunctional components (42). It was revealed that autophagy was inhibited when cells were treated with bupivacaine in a high-glucose environment. The autophagy pathway requires proteins encoded by the autophagy gene (Atg), of which 
ubiquitin-like protein binding systems are involved, including the Atg12-Atg5 binding system and the Atg8/LC3 lipidation system (43). Atg8/LC3 is cleaved by Atg4, which binds to the products of phosphatidylethanolamine. LC3 is then converted from its water-soluble form (LC3-I) to its fat-soluble form (LC3-II). The latter can bind to the autophagosome membrane until the fusion of the autophagosome with the lysosome (44). LC3-II is stably expressed on the autophagosome membrane during the generation and transport of autophagic vacuoles, which is considered a reliable indicator of autophagy. In addition to the UPR signaling, $\mathrm{Ca}^{2+}$ signaling is also involved in autophagy, which involves mammalian target of RAPA (mTOR), and the phosphatidylinositol 3-kinase (PI3K)/Akt and AMPK signaling pathways (45-47). The results of the present study indicated that RAPA induced autophagy, decreased cell apoptosis rates, inhibited PERK-ATF4-CHOP signaling and enhanced IRE1-TRAF2 signaling. In contrast, 3-MA inhibited autophagy and increased apoptosis, resulting in a further imbalance between the two signaling pathways.

There are a number of limitations to the present study. First, PERK and IRE1 signaling pathways were detected immediately after $24 \mathrm{~h}$ high glucose and $24 \mathrm{~h}$ bupivacaine treatment, without collecting data at other time points or without measuring ATF6 signaling. Secondly, the role of autophagy in high glucose and bupivacaine-treated cells was only investigated using one autophagy inducer and inhibitor, respectively. Finally, the interactions between key factors in the PERK-ATF4-CHOP and IRE1-TRAF2 signaling pathways were not assessed in the present study. Further studies to address these limitations are under way.

In the present study, bupivacaine induced cytotoxicity in SH-SY5Y cells under high glucose conditions. This effect was, at least in part, mediated by enhancing cell apoptosis and inhibiting autophagy via the PERK-ATF4-CHOP and IRE1-TRAF2 signaling pathways. The data from the present study suggest that interventions targeting the key factors in these signaling pathways may have important therapeutic potential to decrease bupivacaine-induced cytotoxicity.

\section{Acknowledgements}

Not applicable.

\section{Funding}

The present study was supported by funds from the China Postdoctoral Science Foundation Grant (grant no. 2016M592962) and Beijing Science and Technology Plan (grant nos. Z171100000417035 and Z161100000116074).

\section{Availability of data and materials}

The datasets used and/or analyzed during the current study are available from the corresponding author upon reasonable request.

\section{Authors' contributions}

MG, LSh and YL designed the study. LSu, YM and BW performed the experiments. YL and LSu wrote the manuscript.
YM performed the statistical analyses. All authors have read and approved the final manuscript.

\section{Ethics approval and consent to participate}

Not applicable.

\section{Patient consent for publication}

Not applicable.

\section{Competing interests}

The authors declare that they have no competing interests.

\section{References}

1. Al-Nasser B: Toxic effects of epidural analgesia with ropivacaine $0.2 \%$ in a diabetic patient. J Clin Anesth 16: 220-223, 2004.

2. Moen V, Dahlgren N and Irestedt L: Severe neurological complications after central neuraxial blockades in Sweden 1990-1999. Anesthesiology 101: 950-959, 2004.

3. Capdevila X, Pirat P, Bringuier S, Gaertner E, Singelyn F, Bernard N, Choquet O, Bouaziz H and Bonnet F; French Study Group on Continuous Peripheral NerveBlocks: Continuous peripheral nerve blocks in hospital wards after orthopedic surgery: A multicenter prospective analysis of the quality of postoperative analgesia and complications in 1,416 patients. Anesthesiology 103: 1035-1045, 2005.

4. Lirk P, Birmingham B and Hogan Q: Regional anesthesia in patients with preexisting neuropathy. Int Anesthesiol Clin 49: 144-165, 2011.

5. Kalichman MW and Calcutt NA: Local anesthetic-induced conduction block and nerve fiber injury in streptozotocin-diabetic rats. Anesthesiology 77: 941-947, 1992.

6. Blumenthal S, Borgeat A, Maurer K, Beck-Schimmer B, Kliesch U, Marquardt M and Urech J: Preexisting subclinical neuropathy as a risk factor for nerve injury after continuous ropivacaine administration through a femoral nerve catheter. Anesthesiology 105: 1053-1056, 2006.

7. Angadi DS and Garde A: Subclinical neuropathy in diabetic patients: A risk factor for bilateral lower limb neurological deficit following spinal anesthesia? J Anesth 26: 107-110, 2012.

8. Hebl JR, Kopp SL, Schroeder DR and Horlocker TT: Neurologic complications after neuraxial anesthesia or analgesia in patients with preexisting peripheral sensorimotor neuropathy or diabetic polyneuropathy. Anesth Analg 103: 1294-1299, 2006.

9. Vincent AM, Brownlee M and Russell JW: Oxidative stress and programmed cell death in diabetic neuropathy. Ann N Y Acad Sci 959: 368-383, 2002.

10. Takahashi S, Izawa Y and Suzuki N: Astroglial pentose phosphate pathway rates in response to high-glucose environments. ASN Neuro 4: e00078, 2012.

11. Li L, Ye XP, Lu AZ, Zhou SQ, Liu H, Liu ZJ, Jiang S and Xu SY: Hyperglycemia Magnifies Bupivacaine-Induced Cell Apoptosis Triggered by Mitochondria Dysfunction and Endoplasmic Reticulum Stress. J Neurosci Res 91: 786-798, 2013.

12. Bursch W, Ellinger A, Kienzl H, Török L, Pandey S, Sikorska M, Walker R and Hermann RS: Active cell death induced by the anti-estrogens tamoxifen and in human mammary carcinoma cells (MCF-7) in culture: The role of autophagy. Carcinogenesis 17: 1595-1607, 1996.

13. Pearson GL, Mellett N, Chu KY, Cantley J, Davenport A, Bourbon P, Cosner CC, Helquist P, Meikle PJ and Biden TJ. Lysosomal acid lipase and lipophagy are constitutive negative regulators of glucose-stimulated insulin secretion from pancreatic beta cells. Diabetologia 57: 129-139, 2014.

14. Matsumoto H, Miyazaki S, Matsuyama S, Takeda M, Kawano M, Nakagawa H, Nishimura K and Matsuo S: Selection of autophagy or apoptosis in cells exposed to ER-stress depends on ATF4 expression pattern with or without $\mathrm{CHOP}$ expression. Biol Open 2: 1084-1090, 2013.

15. Cebollero E, Reggiori F and Kraft C: Reticulophagy and ribophagy: regulated degradation of protein production factories. Int J Cell Biol 2012: 182834, 2012. 
16. Hetz C: The unfolded protein response: Controlling cell fate decisions under ER stress and beyond. Nat Rev Mol Cell Biol 3: 89-102, 2012

17. Jäger R, Bertrand MJ, Gorman AM, Vandenabeele P and Samali A: The unfolded protein response at the crossroads of cellular life and death during endoplasmic reticulum stress. Biol Cell 104: 259-270, 2012.

18. Kouroku Y, Fujita E, Tanida I, Ueno T, Isoai A, Kumagai H, Ogawa S, Kaufman RJ, Kominami E and Momoi T: ER stress (PERK/eIF2alpha phosphorylation) mediates the polyglutamine-induced LC3 conversion, an essential step for autophagy formation. Cell Death Differ 14: 230-239, 2007.

19. Fujita E, Kouroku Y, Isoai A, Ueno T, Isoai A, Kumagai H, Ogawa S, Kaufman RJ, Kominami E and Momoi T: Two endoplasmic reticulum-associated degradation systems (ERAD) for the novel variant of the mutant dysferlin; ubiquitin/proteasome ERAD (I) and Autophagy/Lysosome ERAD (II). Hum Mol Genet 16: 618-629, 2007.

20. Scheuner D, Song B, McEwen E, Liu C, Laybutt R, Gillespie P, Saunders T, Bonner-Weir S and Kaufman RJ: Translational control is required for the unfolded protein response and in vivo glucose homeostasis. Mol Cell 7: 1165-1176, 2001.

21. Harding HP, Novoa I, Zhang Y, Zeng H, Wek R, Schapira M and Ron D: Regulated translation initiation controls stress-induced gene expression in mammalian cells. Mol Cell 6: 1099-1108, 2000

22. Yoshida H, Matsui T, Yamamoto A, Okada T and Mori K: XBP1 mRNA is induced by ATF6 and spliced by IRE1 in response to ER stress to produce a highly active transcription factor. Cell 107: 881-891, 2001.

23. Ron D and Hubbard SR: How IRE1 reacts to ER stress. Cell 132: 24-26, 2008.

24. Back SH, Schroder M, Lee K, Zhang K and Kaufman RJ: ER stress signaling by regulated splicing: IRE1/HAC1/XBP1. Methods 35: 395-416, 2005.

25. Wang $M$ and Kaufman RJ: The impact of the endoplasmic reticulum protein-folding environment on cancer development. Nat Rev Cancer 14: 581-597, 2014.

26. Tameire F, Verginadis II and Koumenis C: Cell intrinsic and extrinsic activators of the unfolded protein response in cancer: Mechanisms and targets for therapy. Semin Cancer Biol 33: 3-15, 2015.

27. Oyadomari S and Mori M: Roles of CHOP/GADD153 in endoplasmic reticulum stress. Cell Death Differ 11: 381-389, 2004.

28. Marciniak SJ, Yun CY, Oyadomari S, Novoa I, Zhang Y, Jungreis R, Nagata K, Harding HP and Ron D: CHOP induces death by promoting protein synthesis and oxidation in the stressed endoplasmic reticulum. Genes Dev 18: 3066-3077, 2004.

29. Zinszner H, Kuroda M, Wang XZ, Batchvarova N, Lightfoot RT, Remotti H, Stevens JL and Ron D: CHOP is implicated in programmed cell death in response to impaired function of the endoplasmic reticulum. Genes Dev 12: 982-995, 1998.

30. Davis RJ: Signal transduction by the JNK group of MAP kinases. Cell 103: 239-252, 2000

31. Dhanasekaran DN and Reddy EP: JNK signaling in apoptosis. Oncogene 27: 6245-6251, 2008.

32. Hollien J, Lin JH, Li H, Stevens N, Walter P and Weissman JS Regulated Ire1-dependent decay of messenger RNAs in mammalian cells. J Cell Biol 186: 323-331, 2009.
33. Tay KH, Luan Q, Croft A, Jiang CC, Jin L, Zhang XD and Tseng HY: Sustained IRE1 and ATF6 signaling is important for survival of melanoma cells undergoing ER stress. Cell Signal 26: 287-294, 2014

34. Nakagawa T and Yuan J: Cross-talk between two cysteine protease families: Activation of Caspase12 by calpain in apoptosis. J Cell Biol 150: 887-894, 2000.

35. Lai E, Teodoro T and Volchuk A: Endoplasmic Reticulum Stress: Signaling the Unfolded Proteinv Response. Physiology 22: 193-201, 2007.

36. Nakagawa T, Zhu H, Morishima N, Li E, Xu J, Yankner BA and Yuan J: Caspase12 mediates endoplasmic-reticulum-specific apoptosis and cytotoxicity by amyloid-beta. Nature 403: 98-103, 2000.

37. Rao RV, Hermel E, Castro-Obregon S, del Rio G, Ellerby LM, Ellerby HM and Bredesen DG: Coupling endoplasmic reticulum stress to the cell death program. Mechanism of Caspase activation. J Biol Chem 276: 33869-33874, 2001.

38. Di Giulio AM, Lesma E, Germani E and Gorio A: Inhibition of high glucose-induced protein mono-ADP-ribosylation restores neuritogenesis and sodium-pump activity in SY5Y neuroblastoma cells. J Neurosci Res 57: 663-669, 1999.

39. Walter $P$ and Ron D: The unfolded protein response: From stress pathway to homeostatic regulation. Science 334: 1081-1086, 2011.

40. Ogata M, Hino S, Saito A, Morikawa K, Kondo S, Kanemoto S, Murakami T, Taniguchi M, Tanii I, Yoshinaga K, et al: Autophagy is activated for cell survival after endoplasmic reticulum stress. Mol Cell Biol 26: 9220-9231, 2006.

41. Lin JH, Li H, Yasumura D, Cohen HR, Zhang C, Panning B, Shokat KM, Lavail MM and Walter P: IRE1 signaling affects cell fate during the unfolded protein response. Science 318: 944-949, 2007.

42. Duffy A, Le J, Sausville E and Emadi A: Autophagy modulation: A target for cancer treatment development. Cancer Chemother Pharmacol 75: 439-447, 2015

43. He C and Klionsky DJ: Regulation mechanisms and signaling pathways of autophagy. Annu Rev Genet 43: 67-93, 2009.

44. Hailey DW, Rambold AS, Satpute-Krishnan P, Mitra K, Sougrat R, Kim PK and Lippincott-Schwartz J: Mitochondria supply membranes for autophagosome biogenesis during starvation. Cell 141: 656-667, 2010

45. Hoyer-Hansen M, Bastholm L, Szyniarowski P, Mitra K, Sougrat R, Kim PK and Lippincott-Schwartz J: Control of macro autophagy by calcium, calmodulin-dependent kinase kinase-beta, and Bcl-2. Mol Cell 25: 193-205, 2007.

46. Taylor CW, Taufiq-Ur-Rahman and Pantazaka E: Targeting and clustering of IP3 receptors: Key determinants of spatially organized $\mathrm{Ca}_{2}^{+}$signals. Chaos 19: 037102, 2009.

47. Hyrskyluoto A, Reijonen S, Kivinen J, Lindholm D and Korhonen L: GADD34 mediates cytoprotective autophagy in mutant huntingtin expressing cells via the mTOR pathway. Exp Cell Res 318: 33-42, 2012.

This work is licensed under a Creative Commons

Attribution-NonCommercial-NoDerivatives 4.0 International (CC BY-NC-ND 4.0) License. 